\title{
Effective gene flow patterns across a fragmented landscape in southern Costa Rica for Symphonia globulifera (Clusiaceae); a species with mobile seed and pollen dispersers
}

\author{
Wendy Solís-Hernández ${ }^{1} \&$ Eric J. Fuchs ${ }^{2 *}$ \\ 1. Sistema de Estudios de Posgrado, Escuela de Biología, Universidad de Costa Rica, 11501-2060 San José, Costa Rica; \\ wendysolish@gmail.com \\ 2. Escuela de Biología, Universidad de Costa Rica, 11501-2060 San José, Costa Rica; e.j.fuchs@gmail.com \\ * Correspondence
}

\author{
Received 02-X-2017. Corrected 10-I-2019. Accepted 24-I-2019.
}

\begin{abstract}
In tropical trees, forest fragmentation has been shown to affect mating and gene flow patterns. Mobile dispersal vectors should be less sensitive to fragmented landscapes and may ameliorate the genetic effects of forest fragmentation on plant populations. To test this hypothesis, we analyzed gene flow patterns in Symphonia globulifera, a tropical tree species with highly mobile pollinators and seed dispersers in the Osa Peninsula in southern Costa Rica. We used microsatellites to study genetic diversity and realized gene flow patterns between a continuous forest and a forest fragment. We found high levels of genetic diversity in adults and seedlings at both sites. Parentage analyses suggest near-neighbor matings and frequent long-distance gene flow events. Half the progeny beneath an adult was not sired by that tree and the majority of established seedlings were the result of long-distance gene dispersal. Gene flow from the forest into the fragment was more common than from the fragment into the continuous forests. Despite long distance gene flow events, seedling spatial genetic structure was stronger and extended further in the forest fragment likely due to limited seed dispersal. We conclude that fragmentation affects gene flow in this tropical tree and may compromise its genetic diversity in forest fragments even for a species with mobile pollen and seed vectors.
\end{abstract}

Key words: Pollen flow; seed dispersal; fragmentation; hummingbird pollination; parentage analysis; spatial genetic structure.

Solís-Hernández, W., \& Fuchs, E. J. (2019). Effective gene flow patterns across a fragmented landscape in southern Costa Rica for Symphonia globulifera (Clusiaceae); a species with mobile seed and pollen dispersers. Revista de Biología Tropical, 67(2) Suplemento, S95-S111.

The signatures imposed by fragmentation on genetic diversity of tropical trees have been well summarized (Lowe, Boshier, Ward, Bacles, \& Navarro, 2005; Aguilar, Ashworth, Galetto, \& Aizen, 2006; Aguilar, Quesada, Ashworth, Herrerias-Diego, \& Lobo, 2008). These works predict that adult genetic diversity is rarely going to be impacted by habitat loss and a reduction in diversity is more commonly observed in progenies (Ellstrand \& Elam, 1993; Young, Boyle, \& Brown, 1996;
Lowe et al., 2005; Vranckx, Jacquemyn, Muys, \& Honnay, 2012). Gene flow may ameliorate the negative effects of habitat loss and isolation by increasing effective population size and introducing novel alleles into fragments (White, Boshier, \& Powell, 2002), thus reducing the detrimental effects of drift (Ellstrand \& Elam, 1993; Couvet, 2002). For tropical trees, gene flow across fragmented landscapes partially depends on life history traits, pollinator and seed dispersal agents, as well as the size 
and distribution of forest fragments (Nason \& Hamrick, 1997). Habitat loss was originally expected to reduce gene flow due to an increase in the distance between conspecifics (Ellstrand \& Elam, 1993; Young et al., 1996) and because dispersal vectors (pollinators and seed dispersers) prefer to forage within forests and would avoid traveling over pastures or disturbed habitats to reach other trees (Sih \& Baltus, 1987; Quesada, Stoner, Rosas-Guerrero, PalaciosGuevara, \& Lobo, 2003; Quesada et al., 2004; Breed et al., 2015; Helbig-Bonitz et al., 2015). However, it has been shown that gene flow distances in tropical trees may actually increase in fragmented habitats (Dick, 2001; White et al., 2002; Hanson, Brunsfeld, Finegan, \& Waits, 2008; Rosas, Quesada, Lobo, \& Sork, 2011; Ismail et al., 2012).

Long distance gene flow, however, may be limited to some disperser types or the presence of fragments or isolated individuals that facilitate dispersal between patches (Fuchs \& Hamrick, 2011). Fragments may also receive a higher proportion of long distance gene dispersal events from nearby continuous forest (Sork \& Smouse, 2006; Bacles \& Ennos, 2008). This rescue effect may offset the changes in the mating system and increase the effective population of male donors. However, long-distance gene flow needs to be recurrent and sustained over many generations, as well as originate from multiple sources to reduce the effects of drift (Slatkin, 1985; Bacles \& Ennos, 2008; Breed et al., 2015).

Fragmentation and isolation may change seed and pollen dispersal distances within fragments, changing the spatial distribution of genetic diversity within them (Hanson et al., 2008; De-Lucas, González-Martínez, Vendramin, Hidalgo, \& Heuertz, 2009; Wang, Compton, \& Chen, 2011). Spatial genetic structure (SGS) is expected to increase in fragments due to limited seed dispersal and a reduction in the number of adults (Wang et al., 2011). This in turn may lower effective population sizes, even if pollen flow is extensive (Grivet, Robledo-Arnuncio, Smouse, \& Sork, 2009). Seed movement may have a stronger effect on seedling structure because seeds carry both maternal and paternal gametes and determine where paternal genes will establish (Hamilton, 1999; Grivet et al., 2009).

Fragmentation of tropical ecosystems is likely to continue in the coming years (Achard et al., 2014; Haddad et al., 2015). To effectively manage and conserve tropical tree populations in fragmented and disturbed habitats, gene flow rates need to be estimated. Most studies estimate gene flow distances using open pollinated seeds. However using established seedlings to estimate gene flow jointly considers both pollen and seed flow rates, as well as other factors such as early selection on seedling establishment (Burczyk, DiFazio, \& Adams, 2004; Sebbenn et al., 2011). Realized gene flow estimates, therefore, provide more accurate assessment of gene flow (Bacles, Lowe, \& Ennos, 2006), which in turn may improve conservation and management strategies.

Symphonia globulifera L. f. (Clusiaceae) is a common tropical tree with a wide array of pollen and seed dispersers including large vertebrates such as birds, bats and even tapirs (seed disperser) (Pascarella, 1992; Gill, Fowler, \& Mori, 1998; Torroba-Balmori et al., 2017). Bats have been proposed as the main disperser (Gill et al., 1998). These dispersers are capable of long distance gene flow, thus we hypothesize that $S$. globulifera should be resilient to the detrimental genetic effects of forest fragmentation and, as previously shown for other tropical tree species, we expect a significant proportion of gene flow events between fragments and continuous forests. However, fragmentation may limit pollen and seed dispersal within fragments, which should result in spatial genetic structure (SGS) within them. Previous work by Torroba-Balmori et al. (2017) found significant spatial genetic structure in several populations of $S$. globulifera in Africa and the Neotropics. They found that topographic complexity that modifies seed disperser behavior and consequently, their ability for long distance seed dispersal, impacted the strength of SGS in this species. They suggest that the weaker spatial genetic structure found in Neotropical 
populations could be attribute it to wide-ranging seed dispersers such as bats and large vertebrates that transported seeds efficiently and mixed seed shadows. Therefore, if large vertebrates were also the main dispersers in our site, we would expect to find a similar weak spatial genetic structure and no significant difference between continuous and fragmented habitats.

In this study, we will compare the genetic diversity of adults and seedlings in a continuous forest and a nearby forest fragment in southern Costa Rica and use parentage assignments to study realized gene flow rates across a disturbed landscape. We will also estimate spatial genetic structure within a fragment and a continuous forest, to determine if the spatial structure is affected by fragmentation at this site.

\section{MATERIALS AND METHODS}

Study Species: Symphonia globulifera L. f. (Clusiaceae) is an economically important tropical timber species also known for its medicinal properties (Bayma, Arruda, \& Neto, 1998). It is a hermaphroditic species distributed from southern Mexico to Brazil and it is also found in tropical Africa (Bittrich \& Amaral, 1996). Symphonia globulifera adults reach $10-40 \mathrm{~m}$ in height and are easily recognized by the adventitious roots in the lower trunk and bright yellow resin. The globular flowers are bright red, pink or white, produce copious amounts of nectar and hummingbirds are believed to be the main pollinator (Pascarella, 1992; Aldrich \& Hamrick, 1998). In the wet tropics of Costa Rica, the most frequent flower visitors were stingless bees (Tetragonisca angustula) and the hummingbird Phaethornis longirostris (Sanfiorenzo, Sanfiorenzo, Castro, Waits, \& Finegan, 2018), however in other neotropical forests butterflies and perching birds have been described as potential pollinators (Torroba-Balmori et al., 2017). Fruits are green berries $4-5 \mathrm{~cm}$ in diameter dispersed predominantly by bats, but monkeys (Riba-Hernández \& Stoner, 2005), birds (Pascarella, 1992) and several mammals have also been observed (see table 1 in Torroba-Balmori et al, 2017). In Costa Rica this species is commonly found in wet or very wet tropical rain forests between 0-1700 m a.s.1.

Study area and sampling design: We conducted our study in Golfo Dulce Forest Reserve (GDFR) in the South Pacific coast of

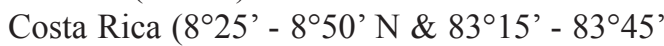
W). This is a very humid tropical forest with annual precipitation between 4000 and 6000 $\mathrm{mm}$ and an average temperature of $27{ }^{\circ} \mathrm{C}$ (Holdridge, 1967). GDFR is composed mainly of private farms whose forested areas are regulated by the Costa Rican government. The GDFR also includes Corcovado National Park. This creates a heterogeneous landscape of forest patches of different sizes surrounded by a matrix of small-scale plantations and pastures (Barrantes et al., 1999).

To understand how fragmentation affects gene flow patterns in S. globulifera, we sampled seedlings and adults in two sites. The first site is a large forest patch ( $\sim 900 \mathrm{ha}$ ) of continuous mature forest, undisturbed for more than 50 years (Barrantes et al., 1999) and a forest fragment of $\sim 40$ ha located about $4 \mathrm{~km}$ south of the continuous forest and separated by grasslands and pastures currently used for cattle grazing. We will refer to these sites as Continuous Forest (CF) and Forest Fragment (FF), respectively. The FF was created in the 1950-60 when land was cleared for cattle farming. This fragment has experienced minor logging, but it is comparable to the larger CF in composition and structure with some secondary growth species (personal observation). Other forest patches of different sizes are located within GDFR but are more than $5 \mathrm{~km}$ away from the FF. We used established seedlings to estimate gene flow patterns and spatial genetic structure. We collected S. globulifera leaves from 10-20 seedlings $(\mathrm{N}=455,15-200 \mathrm{~cm}$ in height) located within a $10 \mathrm{~m}$ radius underneath adult trees. In order to have a similar number of seedlings in both sites, we sampled an area of approximately 10 ha in the CF and 5 ha in the FF for three consecutive years (2009-2011). For each 
TABLE 1

Genetic diversity estimates for Symphonia globulifera (Clusiaceae) adults and seedlings in continuous forest $(\mathrm{CF})$ and in a forest fragment $(\mathrm{FF})$, Costa Rica

\begin{tabular}{clcccccc} 
Habitat Type & \multicolumn{1}{c}{ Age } & $\mathrm{N}$ & $\mathrm{A}$ & $\mathrm{A}_{\mathrm{e}}$ & $\mathrm{Ho}$ & $\mathrm{He}$ & $\mathrm{F}_{\mathrm{IS}}$ \\
Continuous Forest & Adults & 42 & $19.75(4.66)$ & $10.43(2.84)$ & $0.86(0.02)$ & $0.90(0.06)$ & $0.045(\mathrm{P}=0.063)$ \\
& Seedlings & 237 & $27.00(6.67)$ & $10.26(2.25)$ & $0.89(0.02)$ & $0.89(0.05)$ & $-0.003(\mathrm{P}=0.621)$ \\
Forest Fragment & Adults & 19 & $14.25(2.36)$ & $9,64(1.30)$ & $0.83(0.07)$ & $0.91(0.03)$ & $0.089(\mathrm{P}=0.014)$ \\
& Seedlings & 218 & $21.25(4.09)$ & $8.69(1.42)$ & $0.84(0.02)$ & $0.88(0.03)$ & $0.047(\mathrm{P}=0.003)$ \\
\hline
\end{tabular}

$\mathrm{N}$ : sample size, A: Average number of alleles, $\mathrm{A}_{\mathrm{e}}$ : effective allele number, Ho: observed heterozygosity, He: expected heterozygosity, $\mathrm{F}_{\mathrm{IS}}$ : inbreeding coefficient. Standard deviations or p-values are shown in parenthesis.

seedling, we recorded its height, azimuth and distance from the nearest adult. We also collected leaves and cambium tissue from these adults for a total of 42 adults $(\mathrm{DBH}>10 \mathrm{~cm})$ at $\mathrm{CF}$ and 19 adults at FF (Table 1). Given the size of the CF, we only sampled within $100 \mathrm{~m}$ of the forest edge; this sampling scheme was replicated in the FF. Tissues were transported to the laboratory of Molecular Ecology at Escuela de Biología at Universidad de Costa Rica for DNA extraction and microsatellite analyses.

DNA extraction and marker amplification: All samples were stored at $-20{ }^{\circ} \mathrm{C}$ until DNA extraction. Plant tissue was frozen and grounded in liquid nitrogen and DNeasy Plant Mini Kits were used for DNA extraction (Qiagen, Valencia, CA, USA). We genotyped individuals using five microsatellite loci (SSR) developed for S. globulifera: $\mathrm{SgI}$, $\mathrm{SgC} 4$ (Aldrich, Hamrick, Chavarriaga, \& Kochert, 1998), Sg01, Sg06, and Sg10 (Vinson, Amaral, Sampaio, \& Ciampi, 2005). PCR protocols followed the procedure suggested by the Multiplex reaction kit (Qiagen, Hilden, Germany). Thermal cycling conditions were optimized to an initial denaturation at $95^{\circ} \mathrm{C}$ for $15 \mathrm{~min}$, followed by 35 cycles of $30 \mathrm{~s}$ at $94{ }^{\circ} \mathrm{C}, 1 \mathrm{~min}$ and $30 \mathrm{~s}$ at $57^{\circ} \mathrm{C}, 1 \mathrm{~min}$ at $72{ }^{\circ} \mathrm{C}$ and a final extension of $15 \mathrm{~min}$ at $72{ }^{\circ} \mathrm{C}$. Amplification products were visualized by capillary electrophoresis with LIZ 500 size standard marker in an ABI 3130 automatic sequencer (Applied Biosystems Inc., CA, USA). Allele sizes and multilocus genotypes were scored using GeneMarker v.1.91 Demo (SoftGenetics, PA, USA). One hundred samples were genotyped between three and five times to estimate genotyping error rates and the presence of null alleles.

Genetic diversity and structure: Genetic diversity was estimated separately for adults and seedlings within $\mathrm{CF}$ and FF, respectively, using GenAlEx 6.5 (Peakall \& Smouse, 2006) and SpaGeDi v1.4 (Hardy \& Vekemans, 2002). Diversity was quantified as the number of alleles (A), effective number of alleles $\left(\mathrm{A}_{\mathrm{e}}\right)$, observed heterozygosity (Ho), expected heterozygosity $(\mathrm{He})$ and inbreeding coefficient (F), averaged across loci. We also estimated the probability of exclusion using CERvus (Marshall, Slate, Kruuk, \& Pemberton, 1998). With Micro Checker 2004 (Van Oosterhout, Hutchinson, Wills, \& Shipley, 2004) we confirmed the absence of null alleles or allelic dropout. We estimated the genetic structure among adult and seedling populations using $G_{s t}$ statistics calculated in GenoDive2.0 (Meirmans \& Van Tienderen, 2004). Ten thousand permutations were used to assess the significant departure of $G_{s t}$ from random expectations.

Structure 2.3.3 (Pritchard, Stephens, \& Donnelly, 2000) was also used to study the genetic structure of seedlings and adults between sites. The number of clusters that best describes genetic differences among samples was estimated using the admixture model with correlated allele frequencies. Markov chains mixed well after 100000 iterations and we discarded the first 10000 iterations. The 
likelihood of different reproductive clusters $(K)$ was determined by changing cluster numbers between $K=1$ and $K=10$ and averaging 20 repetitions for each $K$ as suggested by Evanno, Regnaut, \& Goudet (2005). The most likely number of clusters that describes the structure of adults and seedlings was determined by the $\Delta K$ method implemented in Structure Harvester (Earl \& von Holdt, 2011). Replicate analyses for the most likely $K$ were analyzed with the "greedy" algorithm in CLUMPP (Jakobsson \& Rosenberg, 2007) to determine the mean probability of identity for all replicate runs. Admixture graphs were created in R (R Development Core Team, 2012).

Realized Gene flow: We used Cervus 3.0.3 (Marshall et al., 1998; Kalinowski, Taper, \& Marshall, 2007) to conduct a parent-pair analysis on seedlings $(\mathrm{N}=455)$ with all sampled adults $(\mathrm{N}=61)$ as potential parents. S. globulifera seedlings collected underneath adult trees were considered a family. Parentpair assignments were performed separately for each seedling family, however we always used all 61 adults as potential parents regardless of site (i.e., continuous forest and forest fragment). Adult genotypes were used to estimate allele frequencies for parentage analyses. In Cervus, we modeled hermaphrodites with the ability to self-pollinate. LOD-scores ( $\log$ of the parental likelihood) and Delta (Difference between the two highest LOD-scores) values were compared with those from 100000 simulated offspring genotypes. The proportion of sampled adults was set at 0.65 for families in $\mathrm{CF}$ and 0.90 for families in FF, assuming we had a larger fraction of unsampled parents in the CF. We chose a genotyping error of 0.01 since we only found conflicting genotypes in $6 / 516$ repeats. Each offspring was assigned to a father and a mother according to the highest LOD values. When a seedling had multiple possible parent pairs, we chose the parents with the highest trio LOD-score (Trio: fathermother-seedling). When a parent could not be assigned, we considered it as a gene flow event from an unsampled adult.
Given the hermaphroditic nature of $S$. globulifera and that many seedlings under an adult were not related to that individual (see results), we did not assume that the closest tree was the seed donor to estimate pollen or seed flow distances, as it would likely bias our results. Instead, we tabulated parentage assignment and determined how many seedlings had both assigned parents within the same local population $\left(\mathrm{P}_{\mathrm{LL}}\right)$. We also tallied the number of seedlings with one local parent and another in a different site $\left(\mathrm{P}_{\mathrm{LF}}\right)$, which very likely represents pollen flow. Finally, we determined how many seedlings had both parents in a different population $\left(\mathrm{P}_{\mathrm{FF}}\right)$, which represent long-distance seed dispersal events. The distance between assigned parents for each seedling was estimated and considered an indirect measure of pollen flow distances. We estimated the distribution of pollen flow distances for seedlings in $\mathrm{CF}$ and FF.

We also performed Bayesian parentage assignments as implemented in the MasterBayes library (Hadfield, Richardson, \& Burke, 2006 ) in the $R$ programming language ( $R$ Development Core Team, 2012). MasterBayes' assignments assume a distance effect based on an exponential distribution. MasterBayes also considers the possibility of unsampled sires and estimates the size of the unsampled population. For details see Hadfield et al. (2006). MasterBayes estimated the effect of distance on parentage assignment separately for each seedling population, using all 61 adults as possible pollen or seed donors. We used uninformative priors for the distance parameter $(\lambda)$, genotyping errors and the number of unsampled adults. Parameters were initially estimated using $250000 \mathrm{MCMC}$ with a burnin of 50000 runs and a thinning parameter of 100 . After 250000 iterations, the number of unsampled sires and dams failed to converge (autocorrelation $r>0.7)$, therefore we used genotyping errors (E1, E2) estimated from uninformative priors, which converged, and fixed those values in further simulations. We also used a distribution with mean $=100$ and $\mathrm{sd}=1$, as a prior for the number of unsampled sires and dams. With 
informative priors, chains mixed well, and all values converged after 250000 iterations, a burnin of 25000 while sampling every $100^{\text {th }}$ iteration (autocorrelation values $r<0.3$ ). We used the posterior probability distribution of $\lambda$, to estimate $95 \%$ confidence intervals (percentiles $\mathrm{P}_{2.5}$ and $\mathrm{P}_{97.5}$ ).

Seedling Spatial Genetic Structure (SGS): Spatial Genetic Structure (SGS) was tested for seedlings separately in both forest types (CF and FF) using SpaGeDi v1.4 (Hardy \& Vekemans, 2002). Adult GPS positions were transformed to corresponding UTM coordinates and seedlings were assigned coordinates based on their relative distance (azimuth and distance) from the nearest geo-referenced adult. Spatial structure was evaluated using the kinship coefficient $\left(F_{i j}\right)$ derived by Loiselle, Sork, Nason, \& Graham (1995). We selected twelve distance categories; the first eight categories are separated by $2.5 \mathrm{~m}$ intervals, up to $20 \mathrm{~m}$ with the remaining categories separated by $10 \mathrm{~m}$ intervals. All categories had more than 100 pairs and represented more than $50 \%$ of sampled population (SpaGeDi). For each distance category, we estimated an average kinship coefficient and its statistical significance by comparing estimates with confidence intervals from the null hypothesis of a random spatial distribution of genotypes. Confidence intervals were derived from 9999 permutations of individuals among geographic coordinates. Standard errors for kinship coefficients per distance class were constructed from jackknife estimates provided by SpaGeDi.

To determine if our sampling design (i.e., collecting seedlings underneath adults) may have affected our SGS estimates, we used a 70 × $50 \mathrm{~m}$ control plot located randomly within the continuous forest $\left(8^{\circ} 46^{\prime} 49.44\right.$ " N $\left.\& 83^{\circ} 22^{\prime} 4.80^{\prime \prime} \mathrm{W}\right)$ where we mapped all $S$. globulifera seedlings for genetic analyses. Due to financial limitations, spatial genetic structure was analyzed on a random sample of 218 seedlings (15-200 $\mathrm{cm}$ in height) using the same twelve distance categories as described above. In all accounts the strength of SGS was estimated using the $S p$ statistic suggested by Vekemans \& Hardy (2004). To compare $S p$ statistics between the forest fragment, the continuous forest and the control plot; CI for the $S p$ statistic was calculated as suggested by (Fenster, Vekemans, \& Hardy, 2003) using 2SD of the $b_{\text {log }}$ estimate (sensu Vekemans \& Hardy, 2004). We used 9999 permutations to estimate the significance of the slope of $b_{\log }$.

\section{RESULTS}

Genetic diversity and Structure: We analyzed 516 individuals (Table 1). Four of the five loci examined were polymorphic and produced reliable scores. Loci had an average of 23 alleles in adults and 29 alleles in seedlings with $100 \%$ polymorphism and a combined exclusion probability of $\mathrm{P}_{\mathrm{E}}=0.999$. High levels of genetic diversity were common for adults and seedlings at both sites (Table 1). Genetic diversity estimates did not differ significantly between generations. However, a mild but significant heterozygote deficit in adults and seedlings in the forest fragment was observed (Table 1). Analysis showed a lack of structure between adults among sites $\left(G_{S T}=0.008, \mathrm{P}=\right.$ 0.4 ) and a very small but significant structure for seedlings $\left(G_{S T}=0.012, \mathrm{P}=0.04\right)$.

Adults were completely admixed and thus were grouped into a single cluster. Two clusters were identified as the most likely grouping for seedlings (Fig. 1). Seedlings showed low levels of admixture and most individuals were assigned to one of the two clusters (probability of assignment $>0.8$ ). The first cluster includes seedlings predominantly from the CF. A larger fraction of the progeny in the FF was assigned to the second cluster which could be interpreted as gene flow events (Fig. 1).

Realized gene flow: CERvUS assigned at least one parent to $396(\mathrm{CF}=201, \mathrm{FF}=$ 195) out of 455 seedlings; the remaining 59 could not be unambiguously assigned to our adult pool and therefore were categorized as gene flow events from un-sampled parents. 51 seedlings had the same tree as a possible 


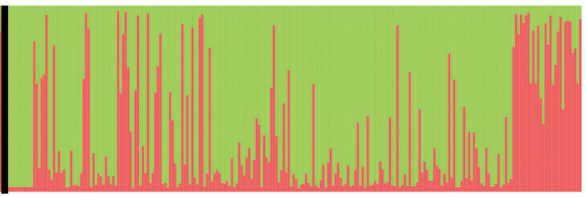

Forest Fragment

Fig 1. Population Bayesian assignment performed by STRUCture for Symphonia globulifera (Clusiaceae) seedlings in a continuous forest and in a forest fragment for two genetic clusters $(K=2)$. Each vertical bar represents an individual and is divided proportionally to the probability of assignment of each individual to a genetic cluster.

parent-pair, which represent selfing events. Selfing was observed in $16.9 \%$ of seedlings in the CF $(34 / 201)$ and $8.7 \%$ of seedlings in the FF (17/195) $\left(\chi^{2}=3.97\right.$, d.f. $\left.=1, P=0.046\right)$. In our sample, more than half of the seedlings growing beneath a tree excluded that same adult as a possible parent. This was the case for 119 from a total of 201 seedlings in the CF, and in 129 out of 195 seedlings in the FF.

Parentage assignment showed that about half of seedlings in CF and FF were the result of local matings with both parents located within the same site as their progeny $\left(\mathrm{P}_{\mathrm{LL}}\right)$ (Table 2). The frequency of seedlings with one local and one external parent $\left(\mathrm{P}_{\mathrm{LF}}\right)$ was higher in the FF $\left(41.7 \%\right.$ vs. $30.5 \%, \mathrm{X}^{2}=5.65$, d.f. $=$ $1, \mathrm{P}=0.017)$. Outcrossed seedlings with both parents in a different site $\left(\mathrm{P}_{\mathrm{FF}}\right)$ were again more frequent in the FF compared to the CF (Table 2). Pollen flow distances follow a bimodal distribution (Fig. 2). Average ( \pm SE) pollen flow distances were $1206.06 \pm 127.5 \mathrm{~m}$ for the $\mathrm{CF}$ and $1684.46 \pm 142.4 \mathrm{~m}$ for the FF, respectively. Within patches, mean pollen flow distances

\section{TABLE 2}

Number of outcrossed seedlings assigned by CERvus to parents in the same population as the seedling $\left(\mathrm{P}_{\mathrm{LL}}\right)$, to one parent in the same population as the seedling and a second parent in another population $\left(\mathrm{P}_{\mathrm{LF}}\right)$, and to parents that were both in a different population as the seedlings $\left(\mathrm{P}_{\mathrm{FF}}\right)$

\begin{tabular}{lcccc} 
& $\mathrm{P}_{\mathrm{FF}}$ & $\mathrm{P}_{\mathrm{LF}}$ & $\mathrm{P}_{\mathrm{LL}}$ & Total \\
Continuous Forest & 5 & 51 & 111 & 167 \\
Forest Fragment & 13 & 78 & 87 & 178 \\
Total & 18 & 129 & 198 & 345 \\
\hline
\end{tabular}

were $228.36 \pm 56.6 \mathrm{~m}$ for the FF and $206.01 \pm$ 59.58 for the CF.

MasterBayes produced comparable results. Confidence intervals $(95 \% \mathrm{CI})$ for the posterior distribution of $\lambda$ showed a slight overlap between FF $\left(\lambda=-0.01957, \mathrm{P}_{2.5}=-0.0246, \mathrm{P}_{97.5}\right.$ $=-0.0148)$ and $\mathrm{CF}\left(\lambda=-0.0307, \mathrm{P}_{2.5}=-0.042\right.$, $\left.\mathrm{P}_{97.5}=-0.021\right)$, but in both cases $\lambda<0$. Negative lambda estimates suggest that parentage assignment is more likely for adults that are closer to seedlings. The $\lambda$ coefficient is greater for the FF compared to the $\mathrm{CF}$, suggesting that the probability of parentage assignments declines faster in CF compared to the FF. In words, parents are located further away from seedlings in the FF. The number of unsampled sires was $167.89\left(\mathrm{P}_{2.5}=142.8, \mathrm{P}_{97.5}=204.9\right)$ for the $\mathrm{CF}$ and $70.07\left(\mathrm{P}_{2.5}=35.1, \mathrm{P}_{97.5}=125.8\right)$ for the FF.

Spatial Genetic Structure: We found significant SGS for seedlings at both sites (Table 3). In CF genetic relatedness between individuals deviated from random expectations for S. globulifera seedlings separated by less than 10m (Fig. 3). SGS decreased sharply after 10 meters and relatedness of seedlings separated by $12.5 \mathrm{~m}$ did not deviate from random expectations. Seedlings underneath a tree crown had an average kinship coefficient of $F_{i j}=0.075$ suggesting a mixture of half-sibs (HS) and unrelated individuals. For seedlings in FF, we observed a similar pattern (Fig. 3). Kinship coefficients decreased as inter-individual distances increased. However, in the forest fragment, SGS continues to be 


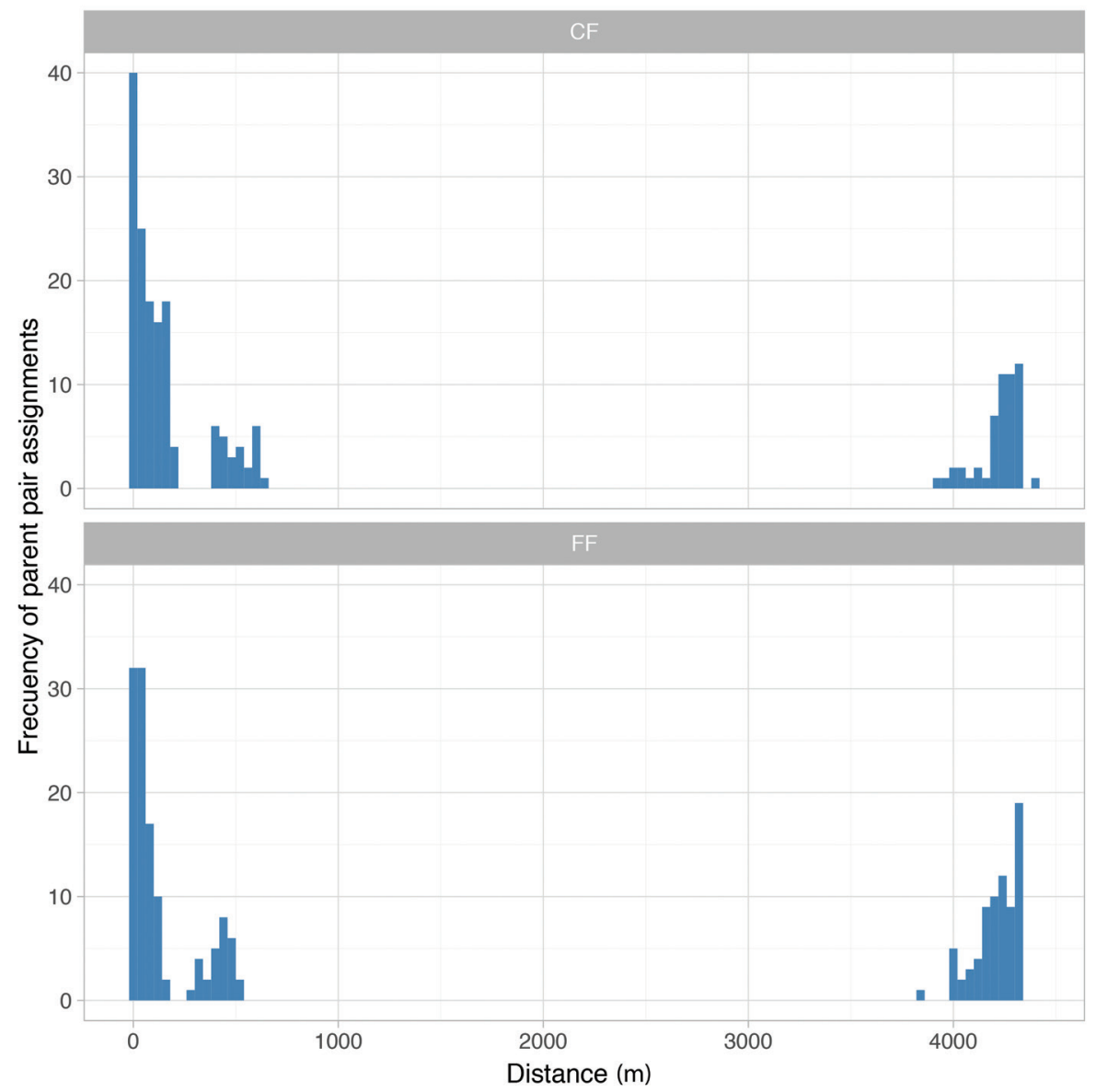

Fig. 2. Frequency distribution of distances between parent pairs (m) assigned with Cervus for seedlings of Symphonia globulifera (Clusiaceae) growing in a continuous forest (CF) and in a forest fragment (FF), Costa Rica.

TABLE 3

Spatial genetic structure statistics for Symphonia globulifera (Clusiaceae) seedlings in two forest types and in a control plot in the Osa Península, Costa Rica

\begin{tabular}{lccc}
\multicolumn{1}{c}{ Location } & $\mathrm{F}_{(1)}$ & $b_{\log }$ & $S p$ \\
Forest Fragment & $0.0745 \pm 0.0032$ & $-0.0223528 \pm 0.004 * * *$ & $0.02415 \pm 0.008$ \\
Continuous Forest & $0.0814 \pm 0.0058$ & $-0.0175115 \pm 0.001 * * *$ & $0.01906 \pm 0.002$ \\
Control plot & $0.0351 \pm 0.0043$ & $-0.0079149 \pm 0.001 * * *$ & $0.00820 \pm 0.002$ \\
\hline
\end{tabular}

$\mathrm{F}_{(1)}$ : kinship coefficient for the first distance category, $b_{l o g}$ : regression slope between kinship coefficient and the log of the distance category, $S p$ : strength of spatial structure. SE for $S p$ was calculated as $2 \mathrm{SE}$ of $b_{\log }$ as suggested by Fenster et al 2003. $* * * \mathrm{P}<0.001$

significant up to $50 \mathrm{~m}$ (Fig. 3). The strength of SGS was also higher in FF as suggested by the $S p$ statistic (Table 3). The $S p$ statistic in the control plot was lower but comparable to the spatial structure observed in the continuous forest (Table 3). Autocorrelograms have similar shapes between CF and FF (Fig. 2) due to similar sampling design. Although sampling in 


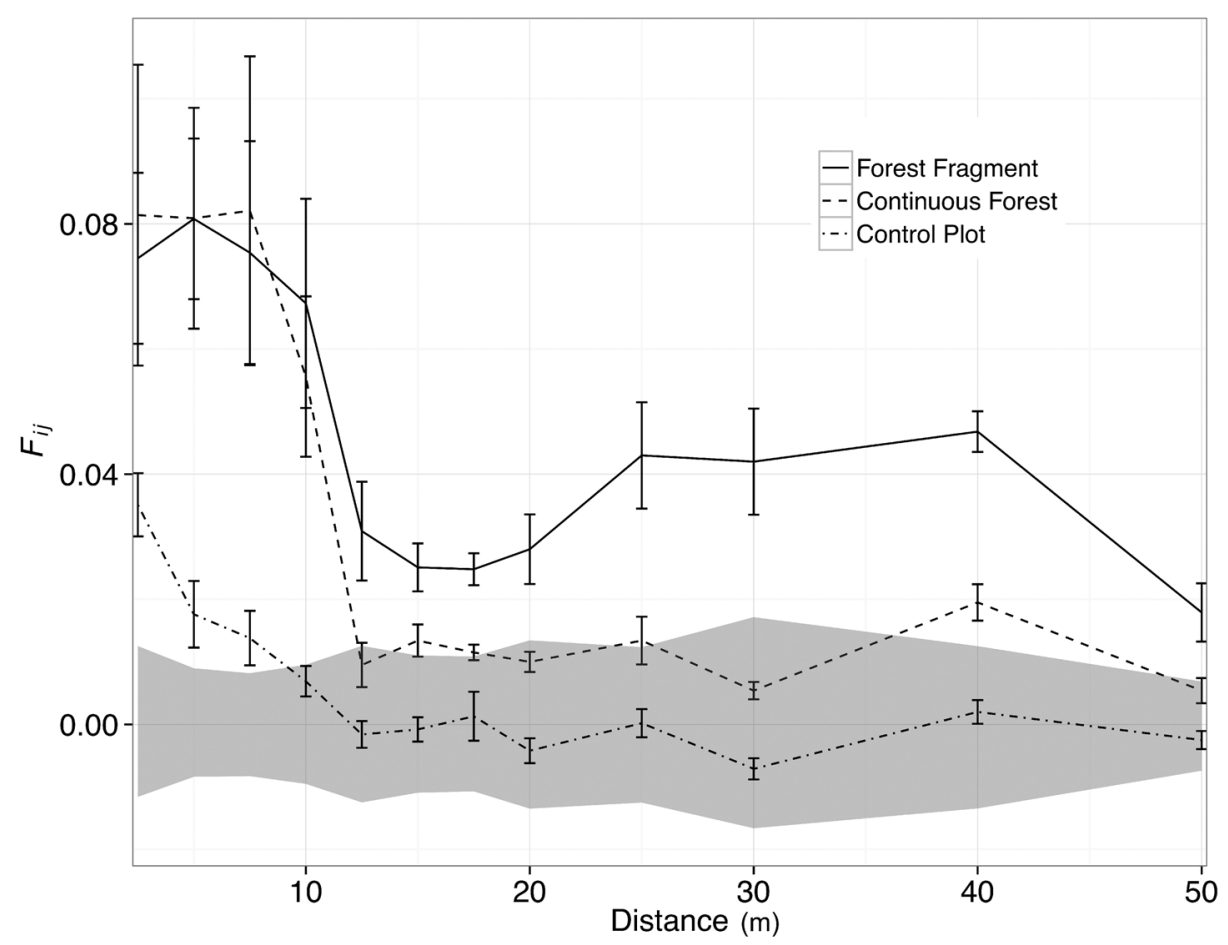

Fig. 3. Kinship estimates relative to distance between seedlings of Symphonia globulifera (Clusiaceae) in a forest fragment (solid line), a continuous forest (dashed line) and a control plot (dash-dot line). See text for details. The shaded area represents the $95 \%$ confidence envelope about the null hypothesis of no spatial genetic structure for the forest fragment, however similar conclusions are drawn with $95 \%$ confidence intervals for the continuous forest. $F_{i j}$ : kinship coefficient. Error bars depict standard errors for kinship coefficient estimates.

the vicinity of adults overestimates SGS, this bias should be similar for both estimates from $\mathrm{CF}$ and $\mathrm{FF}$.

\section{DISCUSSION}

Realized gene flow patterns in Symphonia globulifera, a tropical tree with mobile pollen and seed vectors, in a fragmented landscape in southern Costa Rica suggest that fragmentation may structure the seedling cohort by limiting gene flow among sites. Parentage analyses provided evidence of frequent long-distance gene flow across a fragmented landscape, which possibly occurs more commonly from the continuous forest into the forest fragment. Our results also indicate that fragmentation leads to an increase in the extent of SGS, likely a result of limited seed dispersal within fragments from a limited number of reproductive individuals.

S. globulifera has a wide geographic distribution (Dick \& Heuertz, 2008) with genetically diverse populations (Aldrich et al., 1998; Degen, Bandou, \& Caron, 2004; Vinson et al., 2005; Dick \& Heuertz, 2008; Carneiro, Degen, Kanashiro, de Lacerda, \& Sebbenn, 2009). Congruently, adults and seedlings had both high levels of genetic diversity and fragmentation appears not to have had a significant impact on genetic diversity regardless of age. Only a slight decrease in heterozygosity was observed in adults and progenies in the forest fragment, as well as an increase in inbreeding coefficients. Genetic diversity in adult tropical trees is rarely impacted by fragmentation because not enough time has passed since fragmentation for drift to act upon their diversity 
(Lowe et al., 2005; Julio et al., 2008; Vranckx et al., 2012). The lack of effect observed in the progeny of this study disagrees with other tropical tree studies that reported mild to strong reductions in genetic diversity of the progeny after habitat fragmentation or isolation ( Lowe et al., 2005; Aguilar et al., 2008). These studies attribute the reduction in genetic diversity to a low number of pollen donors and a subsequent increase in geitonogamous matings. Although we see an increase in inbreeding coefficients in the FF, our paternity assignments, challenge the expectation of previous works that suggest that fragmentation increases selfing (Cascante, Quesada, Lobo, \& Fuchs, 2001; Fuchs, Lobo, \& Quesada, 2003). Selfing was more common in the continuous forest. Selfing estimates derived from parentage analyses were comparable to those found by Aldrich \& Hamrick (1998) in a population of $S$. globulifera in Costa Rica, but higher than those reported by Carneiro in Brazil (Carneiro et al., 2009, 2011). Hummingbirds are effective outcross pollen vectors and may fly across fragmented landscapes if they are close to continuous forests (Schulke \& Waser, 2001) as in our case. Another plausible explanation is that selfed seeds have lower fitness or express inbreeding depression, as expected for a predominantly outcrossing species and thus have lower germination rate (Charlesworth \& Charlesworth, 1999; Wang, Hill, Charlesworth, \& Charlesworth, 1999). If germination and establishment is lower in selfed progeny, by sampling plants that were between $15 \mathrm{~cm}$ and $200 \mathrm{~cm}$ in height we would be unable to accurately detect selfing events that were eliminated by inbreeding depression (Konuma, Tsumura, Lee, Lee, \& Okuda, 2000; Hufford \& Hamrick, 2003; Roberts, Ottewell, Whelan, \& Ayre, 2014). By analyzing established seedlings, any change in the mating system caused by fragmentation may not transfer into the seedling cohorts, as selfed seeds may be less fit and fail to germinate. This is an important result suggesting that fragmentation studies that use seeds collected from maternal trees (Cascante et al. 2001, Fuchs et al., 2003) may overestimate the effects of fragmentation on selfing rates.

As expected, our parentage analyses showed that near neighbor matings were the norm in both CF and FF ( Stacy et al., 1996; Carneiro et al., 2009; Segura \& Jimenez Vargas, 2014). Optimal foraging theory predicts that even pollinators that are able to travel long distances should prefer to visit nearby trees (but see Pyke, 1984; Harder \& Barrett, 1996; Bezemer, Krauss, Phillips, Roberts, \& Hopper, 2016). If near neighbor mating continues to be the norm in this species, and the number of possible mates is kept low due to habitat restriction or deterioration, this may eventually lead to an increase in biparental inbreeding and structure in these populations (Hamrick \& Loveless, 1987). Structure within fragments may be an early sign that if isolation persists and densities decrease, genetic diversity will decline, compromising the long term viability of these populations (Newman \& Pilson, 1997; Reed \& Frankham, 2003; Allendorf, Luikart, \& Aitken, 2012). Structure within fragments may also be a result of declines in the populations of pollinators and seed dispersers (Neuschulz, Mueller, Schleuning, \& Böhning-Gaese, 2016). Lower population sizes of gene vectors should increase the detrimental effects of fragmentation by limiting gene flow, lowering genetic diversity and increasing within population genetic structure.

Despite the significant genetic structure found in seedlings, our parent-pair assignment for S. globulifera showed that dispersers effectively transfer pollen and seeds within and between the CF and FF. Within each site, more than half of the progeny underneath the canopy of a tree had another adult as its mother. This was previously observed in other tropical tree species with vertebrate seed dispersers capable of long distance travel (Hardesty, Hubbell, \& Bermingham, 2006; Sezen, Wang, Sork, Leong, \& Smith, 2007; Chazdon, \& Holsinger, 2009). Seed dispersers are probably collecting seeds on one tree and dropping them under another conspecific in their feeding routes. This behavior should increase gene flow distances and 
mix progenies from multiple adults reducing the spatial genetic structure of future cohorts. Mixing progeny from different adults may also aid seedling recruitment by avoiding pathogen attacks (Hardesty, Dick, Kremer, Hubbell, \& Bermingham, 2005) and density-dependent regulation (Marden et al., 2017).

A significant portion of seedlings both in the $\mathrm{CF}$ and in the FF had both parents on a different population located $4 \mathrm{~km}$ away, which represents long distance seed dispersal across a disturbed landscape. If $\mathrm{P}_{\mathrm{LF}}$ and $\mathrm{P}_{\mathrm{FF}}$ are respectively interpreted as indirect estimates of longdistance pollen and seed dispersal frequencies, long-distance gene flow was more likely to occur into the FF.Our results are congruent with previous observations on tropical trees, which show that fragmentation and habitat loss do not prevent long distance gene flow into fragments or isolated individuals, in fact, it may increase the fraction of these long distance gene flow events (Dick, 2001; White et al., 2002; Bacles et al., 2006; Rosas et al., 2011). Seed dispersal represents diploid gene flow and thus has a greater effect on increasing effective population sizes on fragments (Bacles et al., 2006). If seed dispersal is maintained between a continuous forests and a forest fragments across disturbed landscapes, it may reduce the negative effects of drift on fragments.

Maximum likelihood and Bayesian parentpair assignments suggested that a larger fraction of pollen and seed flow events originated in the CF and were directed into the FF. These results propose that in our study system, gene flow patterns are asymmetric. Similar gene flow patterns into smaller fragments or isolated individuals have been found for other tree species (Hanson et al., 2008; Lander, Boshier, \& Harris, 2010; Melo \& Franceschinelli, 2016). Previous work in S. globulifera showed that reproduction by a few dominant individuals might result in asymmetric gene flow from pastures into the continuous forests (Aldrich \& Hamrick, 1998). We did not find evidence of dominant adults as the same number of trees sired progeny in both the $\mathrm{CF}$ as in the FF (data not shown). More gene flow into fragments may be due to pollen or seed disperser behavior, foraging routes (Schulke \& Waser, 2001) or because forest fragments and even isolated individuals may be attractive destinations when travelling across a disturbed landscape deprived of forest cover. Ripperger, Kalko, Rodríguez-Herrera, Mayer, \& Tschapka (2015) showed that Dermanura watsoni, a possible seed disperser of $S$. globulifera, increased foraging distances with increased perturbation and foraged commonly from larger continuous habitats into smaller degraded forest across disturbed matrices. This foraging behavior may help explain the higher proportion of gene flow events into the FF.

Given that we did not sample adults in other fragments, and the large number of estimated unsampled sires, gene flow into fragments may also originate from these sites. Symphonia globulifera is a relatively common species in the area and misidentification due to a limited number of makers is a possibility. However, even with this caveat, our results show that fragments may not be completely disconnected from other populations, at least at the geographic scale of this study. Gene flow into the FF may have a rescue effect (Dick, 2001) by increasing both male and female effective population sizes. This rescue effect may depend on the presence and the proximity of mature forest patches and highlights the importance of keeping large forests as sources of genetic diversity, particularly if fragments act as sinks (Pulliam, 1988). Large forest patches may also house large populations of pollinators and seed dispersers, which may be necessary for long distance dispersal.

We consistently found significant SGS at $\mathrm{CF}, \mathrm{FF}$ and our control plot. Spatial structure, however, was lower than expected for an animal dispersed tropical tree $(S p \in[0.01 \ldots 0.03])$, but comparable to those found for other neotropical populations of $S$. globulifera (Torroba-Balmori et al., 2017). If we compare SGS estimates from $\mathrm{FF}$ and $\mathrm{CF}$, our results suggest that seed dispersal dynamics may change within the FF. Spatial genetic structure in S. globulifera seedlings was stronger and extended further 
in the FF relative to the CF. SGS is caused by a combination of limited pollen and seed dispersal, however, localized seed dispersal is the most likely cause (Epperson, 1992; Hamrick, Murawski, \& Nason, 1993; Torroba-Balmori et al., 2017). Previous evidence corroborates that habitat fragmentation increases SGS in tropical trees (De-Lucas et al., 2009; Wang et al., 2011; Browne, Ottewell, \& Karubian, 2015; Leclerc, Vimal, Troispoux, Périgon, \& Scotti, 2015). Higher SGS in fragments is probably caused by either a change in adult tree density or changes in the abundance and behavior of seed dispersers. For S. globulifera, Degen et al. (2004) and Carneiro et al. (2009) suggested that differences in tree density across populations may shape SGS. Topographic complexity, which may influence seed disperser behavior, and adaptation to microenvironments in a heterogeneous habitat have also been proposed as possible causes of SGS in S. globulifera. However given the close proximity of the $\mathrm{CF}$ and the FF, these factors are unlikely to increase SGS in the FF. The spatial autocorrelogram in the FF is consistent with recruitment from a few individuals at lower densities (Fig. 2a in Hamrick \& Trapnell, 2011). Therefore, we conclude that fewer seed donors may be responsible for recruitment in the FF, which increases the magnitude and length of SGS (Pardini \& Hamrick, 2008). A reduction in the abundance of seed disperser in the FF could also increase the magnitude of SGS compared to the CF, however, we currently do not have information on pollinator or disperser abundances to support this.

SGS in the seedling stage generally decreases in later cohorts due to thinning (Chung, Epperson, \& Chung, 2003; Fuchs \& Hamrick, 2010). However, related individuals may eventually recruit into adult stages. Near neighbor mating and a lower number of possible mates in fragments could lead to an increase in biparental inbreeding and further reductions in genetic diversity within fragments (Hamrick \& Loveless, 1987). This increase in the sub-structuring of genetic diversity within fragments may be an early sign that if fragmentation persists or increases, genetic diversity may continue to decline, compromising the long term viability of populations within fragments (Newman \& Pilson, 1997; Reed \& Frankham, 2003; Allendorf et al., 2012). An increase in the SGS of fragmented populations and significant genetic structure among seedling populations may all be telltale signs that fragmentation has had an impact on the long-term ability of fragments to sustain preexistent levels of genetic diversity.

We would like to highlight that our results are based on one fragment and one continuous forest, which could limit our generalizations. However, since our conclusions are comparable to the growing corpus of information on gene flow patterns in tropical forest fragments and parallels previous results in S. globulifera, one of the most studied tropical tree species (Aldrich \& Hamrick, 1998; Carneiro et al., 2011, 2009; Torroba-Balmori et al, 2017); we are confident that our conclusions contribute valuable information on gene flow dynamics in fragmented tropical landscapes. We suggest that further studies should analyze pollen and seed flow patterns for mobile gene vectors in fragments of different sizes and pollinator and seed disperser densities.

Ethical statement: authors declare that they all agree with this publication and made significant contributions; that there is no conflict of interest of any kind; and that we followed all pertinent ethical and legal procedures and requirements. All financial sources are fully and clearly stated in the acknowledgements section. A signed document has been filed in the journal archives.

\section{ACKNOWLEDGMENTS}

The authors would like to thank D. Jimenez and J. A. Lobo, for field and lab assistance. We would also like to acknowledge funding from International Foundation for Science (IFS D 4358-1), Vicerrectoría de Investigación, Universidad de Costa Rica (111-A8-535) and MICIT-CONICIT (FI-289-09). This work is 
part of Wendy Solís-Hernández master thesis at Universidad de Costa Rica.

\section{RESUMEN}

Patrones efectivos de flujo de genes a través de un paisaje fragmentado en el sur de Costa Rica para una especie con dispersores móviles de polen y semillas; Symphonia globulifera (Clusiaceae). En árboles tropicales se ha demostrado que la fragmentación del bosque afecta los patrones de apareamiento y reduce el flujo génico. Las especies forestales cuyos dispersores y polinizadores son capaces de moverse largas distancias sobre ambientes alterados, serán menos sensibles a los efectos de la fragmentación y podrán intercambiar genes regularmente entre fragmentos. Para probar esta hipótesis, en la Península de Osa en el sur de Costa Rica, estudiamos los patrones de flujo génico de Symphonia globulifera, una especie de árbol tropical con polinizadores y dispersores de semillas altamente móviles. Utilizamos microsatélites para estudiar la diversidad genética y los patrones de flujo génico entre un bosque continuo y un fragmento de bosque. Encontramos altos niveles de diversidad genética tanto en adultos como en plántulas. Los análisis de parentesco indican apareamiento entre vecinos cercanos, sin embargo el flujo génico a larga distancia es frecuente. La mitad de la progenie debajo de un adulto no es engendrada por ese árbol y la mayoría de las plántulas establecidas son el resultado del flujo génico a larga distancia. El flujo de genes desde el bosque continuo hacia el fragmento era más frecuente que el movimiento inverso. A pesar del flujo génico a larga distancia, hay diferencias en frecuencias alélicas entre plántulas y la estructura espacial era más fuerte y se extendía a mayor distancia en el fragmento, probablemente por una dispersión limitada de semillas. Concluimos que la fragmentación afecta los patrones de flujo génico en esta especie de árbol tropical y puede afectar su diversidad genética en paisajes fragmentados, inclusive para una especies con polinizadores y dispersores con alta movilidad.

Palabras clave: Flujo del polen; dispersión de semillas; deforestación; polinización por colibríes; Análisis de parentesco; fragmentación.

\section{REFERENCES}

Achard, F., Beuchle, R., Mayaux, P., Stibig, H.-J., Bodart, C., Brink, A., ... Simonetti, D. (2014). Determination of tropical deforestation rates and related carbon losses from 1990 to 2010. Global Change Biology, 20(8), 2540-2554. DOI: $10.1111 / \mathrm{gcb} .12605$

Aguilar, R., Ashworth, L., Galetto, L., \& Aizen, M. A. (2006). Plant reproductive susceptibility to habitat fragmentation: review and synthesis through a meta-analysis. Ecology Letters, 9(8), 968-980. DOI: 10.1111/j.1461-0248.2006.00927.x
Aguilar, R., Quesada, M., Ashworth, L., Herrerias-Diego, Y., \& Lobo, J. A. (2008). Genetic consequences of habitat fragmentation in plant populations: susceptible signals in plant traits and methodological approaches. Molecular Ecology, 17(24), 5177-5188. DOI: 10.1111/j.1365-294X.2008.03971.x

Aldrich, P. R., \& Hamrick, J. L. (1998). Reproductive dominance of pasture trees in a fragmented tropical forest mosaic. Science, 281(5373), 103-105.

Aldrich, P. R., Hamrick, J. L., Chavarriaga, P., \& Kochert, G. (1998). Microsatellite analysis of demographic genetic structure in fragmented populations of the tropical tree Symphonia globulifera. Molecular Eco$\log y, 7,933-944$

Allendorf, F. W., Luikart, G. H., \& Aitken, S. N. (2012). Conservation and the Genetics of Populations ( $2^{\text {nd }}$ ed.). Hoboken: Wiley-Blackwell.

Bacles, C. F. E., \& Ennos, R. A. (2008). Paternity analysis of pollen-mediated gene flow for Fraxinus excelsior L. in a chronically fragmented landscape. Heredity, 101(4), 368-380. DOI: 10.1038/hdy.2008.66

Bacles, C. F. E., Lowe, A. J., \& Ennos, R. A. (2006). Effective seed dispersal across a fragmented landscape. Science, 311(5761), 628. DOI: 10.1126/ science. 1121543

Barrantes, G., Jiménez, Q., Lobo, J., Maldonado, T., Quesada, M., \& Quesada, R. (1999). Evaluacion de los planes de manejo forestal autorizados en el periódo 1997-1999 en la Peninsula de Osa. Cumplimiento de normas tecnicas, ambientales e impacto sobre el bosque natural. Puerto Jimenez, Costa Rica: Fundacion Cecropia. Recuperado de http://www.apreflofas. or.cr/spa/documentos/informe_cecropia.pdf

Bayma, J. C., Arruda, M. S., \& Neto, M. S. (1998). A prenylated xanthone from the bark of Symphonia globulifera. Phytochemistry, 49(4), 1159-1160.

Bezemer, N., Krauss, S. L., Phillips, R. D., Roberts, D. G., \& Hopper, S. D. (2016). Paternity analysis reveals wide pollen dispersal and high multiple paternity in a small isolated population of the bird-pollinated Eucalyptus caesia (Myrtaceae). Heredity. DOI: 10.1038/hdy.2016.61

Bittrich, V., \& Amaral, M. C. E. (1996). Pollination biology of Symphonia globulifera (Clusiaceae). Plant Systematics and Evolution, 200(1-2), 101-110. DOI: 10.1007/BF00984751

Breed, M. F., Ottewell, K. M., Gardner, M. G., Marklund, M. H. K., Dormontt, E. E., \& Lowe, A. J. (2015). Mating patterns and pollinator mobility are critical traits in forest fragmentation genetics. Heredity, 115(2), 108-114. DOI: 10.1038/hdy.2013.48

Browne, L., Ottewell, K., \& Karubian, J. (2015). Shortterm genetic consequences of habitat loss and 
fragmentation for the neotropical palm Oenocarpus bataua. Heredity, 115(5), 389-395. DOI: 10.1038/ hdy. 2015.35

Burczyk, J., DiFazio, S. P., \& Adams, W. T. (2004). Gene flow in forest trees: how far do genes really travel? Forest Genetics, 11(3/4), 179.

Carneiro, F. S., Degen, B., Kanashiro, M., de Lacerda, A. E. B., \& Sebbenn, A. M. (2009). High levels of pollen dispersal detected through paternity analysis from a continuous Symphonia globulifera population in the Brazilian Amazon. Forest Ecology and Management, 258(7), 1260-1266. DOI: 10.1016/j. foreco.2009.06.019

Carneiro, F. S., Lacerda, A. E. B., Lemes, M. R., Gribel, R., Kanashiro, M., Wadt, L. H. O., \& Sebbenn, A. M. (2011). Effects of selective logging on the mating system and pollen dispersal of Hymenaea courbaril L. (Leguminosae) in the Eastern Brazilian Amazon as revealed by microsatellite analysis. Forest Ecology and Management, 262(9), 1758-1765. DOI: 10.1016/j.foreco.2011.07.023

Cascante, A., Quesada, M., Lobo, J. A., \& Fuchs, E. J. (2001). Effects of dry tropical forest fragmentation on the reproductive success and genetic structure of the tree Samanea saman. Conservation Biology, 16(1), 137-147.

Charlesworth, B., \& Charlesworth, D. (1999). The genetic basis of inbreeding depression. Genetical Research, 74(3), 329-340.

Chung, M. Y., Epperson, B. K., \& Chung, M. G. (2003). Genetic structure of age classes in Camellia japonica (Theaceae). Evolution, 57(1), 62-73.

Couvet, D. (2002). Deleterious effects of restricted gene flow in fragmented populations. Conservation Biology, 16(2), 369-376.

Degen, B., Bandou, E., \& Caron, H. (2004). Limited pollen dispersal and biparental inbreeding in Symphonia globulifera in French Guiana. Heredity, 93(6), 585591. DOI: $10.1038 /$ sj.hdy. 6800560

De-Lucas, A. I., González-Martínez, S. C., Vendramin, G. G., Hidalgo, E., \& Heuertz, M. (2009). Spatial genetic structure in continuous and fragmented populations of Pinus pinaster Aiton. Molecular Ecology, 18(22), 4564-4576. DOI: 10.1111/j.1365-294X.2009.04372.x

Dick, C. W. (2001). Genetic rescue of remnant tropical trees by an alien pollinator. Proceedings of the Royal Society of London Series B-Biological Sciences, 268, 2391-2396.

Dick, C. W., \& Heuertz, M. (2008). The complex biogeographic history of a widespread tropical tree species. Evolution, 62(11), 2760-2774. DOI: 10.1111/j.1558-5646.2008.00506.x
Earl, D. A., \& von Holdt, B. M. (2011). STRUCTURE HARVESTER: a website and program for visualizing STRUCTURE output and implementing the Evanno method. Conservation Genetics Resources, 4(2), 359361. DOI: $10.1007 / \mathrm{s} 12686-011-9548-7$

Ellstrand, N. C., \& Elam, D. R. (1993). Population genetic consequences of small population size: Implications for plant conservation. Annual Review of Ecology and Systematics, 24, 217-242.

Epperson, B. (1992). Spatial structure of genetic variation within populations of forest trees. New Forests, 6(1), 257-278.

Evanno, G., Regnaut, S., \& Goudet, J. (2005). Detecting the number of clusters of individuals using the software STRUCTURE: a simulation study. Molecular Ecology, 14(8), 2611-2620. DOI: 10.1111/j.1365-294X.2005.02553.x

Fenster, C. B., Vekemans, X., \& Hardy, O. J. (2003). Quantifying gene flow from spatial genetic structure data in a metapopulation of Chamaecrista fasciculata (Leguminosae). Evolution. DOI: 10.1111/j.00143820.2003.tb00311.x

Fuchs, E. J., \& Hamrick, J. L. (2010). Spatial genetic structure within size classes of the endangered tropical tree Guaiacum sanctum (Zygophyllaceae). American Journal of Botany, 97(7), 1200-1207. DOI: 10.3732/ ajb.0900377

Fuchs, E. J., \& Hamrick, J. L. (2011). Mating system and pollen flow between remnant populations of the endangered tropical tree, Guaiacum sanctum (Zygophyllaceae). Conservation Genetics, 12(1), 175-185. DOI: $10.1007 / \mathrm{s} 10592-010-0130-8$

Fuchs, E. J., Lobo, J. A., \& Quesada, M. (2003). Effects of forest fragmentation and flowering phenology on the reproductive success and mating patterns of the tropical dry forest tree Pachira quinata. Conservation Biology, 17(1), 149-157. DOI: 10.1046/j.1523-1739.2003.01140.x

Gill, G. E., Fowler, R. T., \& Mori, S. A. (1998). Pollination biology of Symphonia globulifera (Clusiaceae) in Central French Guiana. Biotropica, 30(1), 139-144.

Grivet, D., Robledo-Arnuncio, J. J., Smouse, P. E., \& Sork, V. L. (2009). Relative contribution of contemporary pollen and seed dispersal to the effective parental size of seedling population of California valley oak (Quercus lobata Née). Molecular Ecology, 18(19), 3967-3979. DOI: 10.1111/j.1365-294X.2009.04326.x

Haddad, N. M., Brudvig, L. A., Clobert, J., Davies, K. F., Gonzalez, A., Holt, R. D., ... Townshend, J. R. (2015). Habitat fragmentation and its lasting impact on Earth's ecosystems. Science Advances, 1(2), e1500052. DOI: $10.1126 /$ sciadv. 1500052 
Hadfield, J. D., Richardson, D. S., \& Burke, T. (2006). Towards unbiased parentage assignment: combining genetic, behavioural and spatial data in a Bayesian framework. Molecular Ecology, 15(12), 3715-3730. DOI: $10.1111 / \mathrm{j} .1365-294 X .2006 .03050 . x$

Hamilton, M. B. (1999). Tropical tree gene flow and seed dispersal. Nature, 401(6749), 129-130. DOI: $10.1038 / 43597$

Hamrick, J. L., \& Loveless, M. D. (1987). Associations between the breeding system and the genetic-structure of tropical tree populations. American Journal of Botany, 74(5), 642-642.

Hamrick, J. L., Murawski, D. A., \& Nason, J. D. (1993). The influence of seed dispersal mechanisms on the genetic structure of tropical tree populations. Vegetatio, 107(108), 281-297.

Hamrick, J. L., \& Trapnell, D. (2011). Using population genetic analyses to understand seed dispersal patterns. Acta Oecologica, 37(6), 641-649.

Hanson, T. R., Brunsfeld, S. J., Finegan, B., \& Waits, L. P. (2008). Pollen dispersal and genetic structure of the tropical tree Dipteryx panamensis in a fragmented Costa Rican landscape. Molecular Ecology, 17(8), 2060-2073. DOI: 10.1111/j.1365-294X.2008.03726.x

Harder, L. D., \& Barrett, S. C. H. (1996). Pollen Dispersal and Mating Patterns in Animal-Pollinated Plants. In D. G. Lloyd \& S. C. H. Barrett (Eds.), Floral Biology (pp. 140-190). USA: Springer. DOI: 10.1007/978-1-4613-1165-2 6

Hardesty, B. D., Dick, C. W., Kremer, A., Hubbell, S., \& Bermingham, E. (2005). Spatial genetic structure of Simarouba amara Aubl. (Simaroubaceae), a dioecious, animal-dispersed Neotropical tree, on Barro Colorado Island, Panama. Heredity, 95(4), 290-297.

Hardesty, B. D., Hubbell, S. P., \& Bermingham, E. (2006). Genetic evidence of frequent long-distance recruitment in a vertebrate-dispersed tree. Ecology Letters, 9(5), 516-525. DOI: 10.1111/j.1461-0248.2006.00897.x

Hardy, O. J., \& Vekemans, X. (2002). SPAGeDi: a versatile computer program to analyse spatial genetic structure at the individual or population levels. Molecular Ecology Notes, 2(4), 618-620. DOI: 10.1046/j.1471-8286.2002.00305.x

Helbig-Bonitz, M., Ferger, S. W., Böhning-Gaese, K., Tschapka, M., Howell, K., \& Kalko, E. K. V. (2015). Bats are not birds - different responses to human land-use on a tropical mountain. Biotropica, 47(4), 497-508. DOI: $10.1111 /$ btp.12221

Holdridge, L. R. (1967). Life zone ecology. San Jose, Costa Rica: Tropical Science Center.

Hufford, K. M., \& Hamrick, J. L. (2003). Viability selection at three early life stages of the tropical tree,
Platypodium elegans (Fabaceae, Papilionoideae). Evolution, 57(3), 518-526.

Ismail, S. A., Ghazoul, J., Ravikanth, G., Uma Shaanker, R., Kushalappa, C. G., \& Kettle, C. J. (2012). Does long-distance pollen dispersal preclude inbreeding in tropical trees? Fragmentation genetics of Dysoxylum malabaricum in an agro-forest landscape. Molecular Ecology, 21(22), 5484-5496. DOI: 10.1111/ mec. 12054

Jakobsson, M., \& Rosenberg, N. A. (2007). CLUMPP: a cluster matching and permutation program for dealing with label switching and multimodality in analysis of population structure. Bioinformatics, 23(14), 1801-1806. DOI: 10.1093/bioinformatics/btm233

Julio, N., Sobral, A., Dueñas, J. R., Di Rienzo, J., Renison, D., \& Hensen, I. (2008). RAPD and ISSR markers indicate diminished gene flow due to recent fragmentation of Polylepis australis woodlands in central Argentina. Biochemical Systematics and Ecology, 36(5-6), 329-335. DOI: 10.1016/j.bse.2007.10.007

Kalinowski, S. T., Taper, M. L., \& Marshall, T. C. (2007). Revising how the computer program Cervus accommodates genotyping error increases success in paternity assignment. Molecular Ecology, 16(5), 1099-1106. DOI: 10.1111/j.1365-294X.2007.03089.x

Konuma, A., Tsumura, Y., Lee, C. T., Lee, S. L., \& Okuda, T. (2000). Estimation of gene flow in the tropicalrainforest tree Neobalanocarpus heimii (Dipterocarpaceae), inferred from paternity analysis. Molecular Ecology, 9(11), 1843-1852.

Lander, T. A., Boshier, D. H., \& Harris, S. A. (2010). Fragmented but not isolated: Contribution of single trees, small patches and long-distance pollen flow to genetic connectivity for Gomortega keule, an endangered Chilean tree. Biological Conservation, 143(11), 2583-2590. DOI: 10.1016/j.biocon.2010.06.028

Leclerc, T., Vimal, R., Troispoux, V., Périgon, S., \& Scotti, I. (2015). Life after disturbance (I): changes in the spatial genetic structure of Jacaranda copaia (Aubl.) D. Don (Bignonianceae) after logging in an intensively studied plot in French Guiana. Annals of Forest Science. DOI: 10.1007/s13595-015-0462-0

Loiselle, B. A., Sork, V. L., Nason, J., \& Graham, C. (1995). Spatial genetic structure of a tropical understory shrub, Psychotria officinalis (Rubiaceae). American Journal of Botany, 82(11), 1420-1425.

Lowe, A. J., Boshier, D., Ward, M., Bacles, C. F. E., \& Navarro, C. (2005). Genetic resource impacts of habitat loss and degradation; reconciling empirical evidence and predicted theory for neotropical trees. Heredity, 95(4), 255-273.

Marden, J. H., Mangan, S. A., Peterson, M. P., Wafula, E., Fescemyer, H. W., Der, J. P., ... Comita, L. S. (2017). Ecological genomics of tropical trees: how local 
population size and allelic diversity of resistance genes relate to immune responses, cosusceptibility to pathogens, and negative density dependence. Molecular Ecology, 26(9), 2498-2513. DOI: 10.1111/ mec.13999

Marshall, T. C., Slate, J., Kruuk, L. E., \& Pemberton, J. M. (1998). Statistical confidence for likelihood-based paternity inference in natural populations. Molecular Ecology, 7(5), 639-655.

Meirmans, P. G., \& Van Tienderen, P. H. (2004). Genotype and genodive: two programs for the analysis of genetic diversity of asexual organisms. Molecular Ecology Notes, 4(4), 792-794. DOI: 10.1111/j.1471-8286.2004.00770.x

Melo, A. T. de O., \& Franceschinelli, E. V. (2016). Gene flow and fine-scale spatial genetic structure in Cabralea canjerana (Meliaceae), a common tree species from the Brazilian Atlantic forest. Journal of Tropical Ecology, 32(02), 135-145. DOI: 10.1017/ S0266467416000067

Nason, J. D., \& Hamrick, J. L. (1997). Reproductive and genetic consequences of forest fragmentation: Two case studies of neotropical canopy trees. Journal of Heredity, 88(4), 264-276.

Neuschulz, E. L., Mueller, T., Schleuning, M., \& BöhningGaese, K. (2016). Pollination and seed dispersal are the most threatened processes of plant regeneration. Scientific Reports, 6, 29839. DOI: 10.1038/srep29839

Newman, D., \& Pilson, D. (1997). Increased probability of extinction due to decreased genetic effective population size: experimental populations of Clarkia pulchella. Evolution, 51(2), 354. DOI: 10.2307/2411107

Pardini, E. A., \& Hamrick, J. L. (2008). Inferring recruitment history from spatial genetic structure within populations of the colonizing tree Albizia julibrissin (Fabaceae). Molecular Ecology, 17(12), 2865-2879. DOI: 10.1111/j.1365-294X.2008.03807.x

Pascarella, J. (1992). Notes on flowering phenology, nectar robbing and pollination of Symphonia globulifera LF (Clusiaceae) in a lowland rain forest in Costa Rica. Brenesia, 38, 83-86.

Peakall, R. \& Smouse, P. E. (2006). GenAlEx 6: genetic analysis in Excel. Population genetic software for teaching and research. Molecular Ecology Notes, 6, 288-295.

Pritchard, J. K., Stephens, M., \& Donnelly, P. (2000). Inference of population structure using multilocus genotype data. Genetics, 155(2), 945-959.

Pulliam, H. R. (1988). Sources, sinks, and population regulation. American naturalist, 652-661.

Pyke, G. H. (1984). Optimal Foraging Theory: A Critical Review. Annual Review of Ecology and
Systematics, 15(1), 523-575. DOI: 10.1146/annurev. es. 15.110184 .002515

Quesada, M., Stoner, K. E., Lobo, J. A., Herrerias-Diego, Y., Palacios-Guevara, C., Munguia-Rosas, M. A., ... Rosas-Guerrero, V. (2004). Effects of forest fragmentation on pollinator activity and consequences for plant reproductive success and mating patterns in batpollinated Bombacaceous trees. Biotropica, 36(2), 131-138. DOI: 10.1111/j.1744-7429.2004.tb00305.x

Quesada, M., Stoner, K. E., Rosas-Guerrero, V., PalaciosGuevara, C., \& Lobo, J. A. (2003). Effects of habitat disruption on the activity of nectarivorous bats (Chiroptera: Phyllostomidae) in a dry tropical forest: implications for the reproductive success of the neotropical tree Ceiba grandiflora. Oecologia, 135(3), 400-406. DOI: 10.1007/s00442-003-1234-3

R Development Core Team. (2012). R: A language and environment for statistical computing. Vienna, Austria: R Foundation for Statistical Computing. Retrieved from http://www.R-project.org

Reed, D. H., \& Frankham, R. (2003). Correlation between fitness and genetic diversity. Conservation biology, 17(1), 230-237.

Riba-Hernández, P., \& Stoner, K. E. (2005). Massive destruction of Symphonia globulifera (Clusiaceae) flowers by Central American Spider monkeys (Ateles geoffroyi). Biotropica, 37(2), 274-278. DOI: 10.1111/j.1744-7429.2005.00037.x

Ripperger, S. P., Kalko, E. K. V., Rodríguez-Herrera, B., Mayer, F., \& Tschapka, M. (2015). Frugivorous bats maintain functional habitat connectivity in agricultural landscapes but rely strongly on natural forest fragments. PLOS ONE, 10(4). DOI: 10.1371/journal. pone. 0120535

Roberts, D. G., Ottewell, K. M., Whelan, R. J., \& Ayre, D. J. (2014). Is the post-disturbance composition of a plant population determined by selection for outcrossed seedlings or by the composition of the seedbank? Heredity, 112(4), 409.

Rosas, F., Quesada, M., Lobo, J. A., \& Sork, V. L. (2011). Effects of habitat fragmentation on pollen flow and genetic diversity of the endangered tropical tree Swietenia humilis (Meliaceae). Biological Conservation, 144(12), 3082-3088. DOI:10.1016/j. biocon.2011.10.003

Sanfiorenzo, A., Sanfiorenzo, M., Castro, R. V., Waits, L., \& Finegan, B. (2018).Potential pollinators of understory populations of Symphonia globulifera in the Neotropics. Journal of Pollination Ecology, 22(1), 1-10. Retrieved from http://www.pollinationecology. org/index.php?journal=jpe \&page $=$ article $\&$ op $=$ view \&path $\% 5 \mathrm{~B} \% 5 \mathrm{D}=405$

Schulke, B., \& Waser, N. (2001). Long-distance pollinator flights and pollen dispersal between populations of 
Delphinium nuttallianum. Oecologia, 127(2), 239245. DOI: $10.1007 / \mathrm{s} 004420000586$

Sebbenn, A. M., Carvalho, A. C. M., Freitas, M. L. M., Moraes, S. M. B., Gaino, A. P. S. C., da Silva, J. M., ... Moraes, M. L. T. (2011). Low levels of realized seed and pollen gene flow and strong spatial genetic structure in a small, isolated and fragmented population of the tropical tree Copaifera langsdorffii Desf. Heredity, 106(1), 134-145. DOI: 10.1038/ hdy. 2010.33

Segura, J. L., \& Jimenez Vargas, D. (2014). Pollen dispersal patterns in a fragmented population of Carapa nicaraguensis (Meliaceae). International Journal of Plant Sciences, 175(2), 176-185. DOI: 10.1086/673304

Sezen, U. U., Chazdon, R. L., \& Holsinger, K. E. (2009). Proximity is not a proxy for parentage in an animaldispersed Neotropical canopy palm. Proceedings of the Royal Society B: Biological Sciences, 276(1664), 2037-2044. DOI: $10.1098 /$ rspb.2008.1793

Sih, A., \& Baltus, M.-S. (1987). Patch size, pollinator behavior, and pollinator limitation in catnip. Ecology, 1679-1690.

Slatkin, M. (1985). Gene Flow In Natural-Populations. Annual Review Of Ecology And Systematics, 16, 393-430.

Sork, V. L., \& Smouse, P. E. (2006). Genetic analysis of landscape connectivity in tree populations. Landscape Ecology, 21(6), 821-836. DOI: 10.1007/ s10980-005-5415-9

Stacy, E. A., Hamrick, J. L., Nason, J. D., Hubbell, S. P., Foster, R. B., \& Condit, R. (1996). Pollen dispersal in low-density populations of three neotropical tree species. American Naturalist, 148(2), 275-298.

Torroba-Balmori, P., Budde, K. B., Heer, K., GonzálezMartínez, S. C., Olsson, S., Scotti-Saintagne, C., ... Heuertz, M. (2017). Altitudinal gradients, biogeographic history and microhabitat adaptation affect fine-scale spatial genetic structure in African and Neotropical populations of an ancient tropical tree species. PloS ONE, 12(8), e0182515.

Van Oosterhout, C., Hutchinson, W. F., Wills, D. P., \& Shipley, P. (2004). MICRO-CHECKER: software for identifying and correcting genotyping errors in microsatellite data. Molecular Ecology Notes, 4(3), 535-538.

Vekemans, X., \& Hardy, O. J. (2004). New insights from fine-scale spatial genetic structure analyses in plant populations. Molecular Ecology, 13(4), 921-935.

Vinson, C. C., Amaral, A. C., Sampaio, I., \& Ciampi, A. Y. (2005). Characterization and isolation of DNA microsatellite primers for the tropical tree, Symphonia globulifera Linn. f. Molecular Ecology Notes, 5(2), 202-204. DOI: 10.1111/j.1471-8286.2005.00876.x

Vranckx, G., Jacquemyn, H., Muys, B., \& Honnay, O. (2012). Meta-analysis of susceptibility of woody plants to loss of genetic diversity through habitat fragmentation. Conservation Biology, 26(2), 228237. DOI: $10.1111 / \mathrm{j} .1523-1739.2011 .01778 . \mathrm{x}$

Wang, B. C., Sork, V. L., Leong, M. T., \& Smith, T. B. (2007). Hunting of Mammals Reduces Seed Removal and Dispersal of the Afrotropical Tree Antrocaryon klaineanum (Anacardiaceae). Biotropica, 39(3), 340347. DOI: $10.1111 / \mathrm{j} .1744-7429.2007 .00275 . \mathrm{x}$

Wang, J., Hill, W., Charlesworth, D., \& Charlesworth, B. (1999). Dynamics of inbreeding depression due to deleterious mutations in small populations: mutation parameters and inbreeding rate. Genetical Research, 74(2), 165-178.

Wang, R., Compton, S. G., \& Chen, X.-Y. (2011). Fragmentation can increase spatial genetic structure without decreasing pollen-mediated gene flow in a wind-pollinated tree. Molecular Ecology, 20(21), 4421-4432. DOI: 10.1111/j.1365-294X.2011.05293.x

White, G. M., Boshier, D. H., \& Powell, W. (2002). Increased pollen flow counteracts fragmentation in a tropical dry forest: An example from Swietenia humilis Zuccarini. Proceedings of the National Academy of Sciences of the United States of America, 99(4), 2038-2042.

Young, A., Boyle, T., \& Brown, T. (1996). The population genetic consequences of habitat fragmentation for plants. Trends in Ecology and Evolution, 11(10), 413-418. 